\title{
KONSEP NEGARA DAN RELEVANSI TERHADAP NKRI PERSPEKTIF EMHA AINUN NADJIB
}

\author{
Muh. Ainun Najib, Budy Sugandi, Ismail Suardi Wekke \\ Universitas Islam Negeri Sunan Kalijaga Yogyakarta | DIY Yogyakarta \\ Universitas Nahdatul Ulama Indonesia | Jakarta \\ Sekolah Tinggi Agama Islam Negeri (STAIN) Sorong | Papua Barat \\ manajib@gmail.com
}

\begin{abstract}
State and power are two things that cannot be separated from one another. Substantially, both have the main purpose of creating prosperity for the people. In fact, the Indonesia's democratic system seems to be imperfect. Therefore, it needs to have reorientation and revitalization of the concept in its implementation. The thought of Muhammad Ainun Najib (Cak Nun), in this context, is an alternative offer, such as; first, there is a distinction between state institutions and government institutions, between the head of state and the head of government, for the sake of creating political stability and the administration of the good governance; second, the criteria of a leader need to have scientific quality that is not only knowing issues of the personal and group interests, but also understanding in detail about the life of the regions; third, Indonesia should have five national pillars such as people, Indonesian National Army (TNI), intellectuals, customs and culture, as well as spiritual powers. Those five pillars are supposed to support the upright and the solid state of the Republic of Indonesia.
\end{abstract}

Keywords: Concept of the country, Cak Nun, Indonesia.

Abstrak: Negara dan kekuasaan merupakan dua hal yang tidak dapat dipisahkan satu sama lain, yang secara substansial mempunyai tujuan utama menciptakan kesejahteraan bagi rakyatnya. Sistem demokrasi Indonesia terbukti masih belum sempurna, perlu ada reorientasi, dan revitalisasi konsep dalam pelaksanaanya. Pemikiran Muhammad Ainun Najib (Cak Nun) dalam konteks ini menjadi alternatif yang dapat ditawarkan misalnya; pertama, adanya pembedaan antara lembaga negara dan lembaga pemerintah, antara kepala Negara dan kepala pemerintahan, demi terciptanya kestabilan politik dan penyelenggaraan pemerintahan yang baik dalam suatu negara; kedua, kriteria seorang pemimpin perlu memiliki kualitas keilmuan yang tidak hanya sekedar mengetahui persoalan yang bersifat kepentingan pribadi dan golongan,

AL-DAULAH: JURNAL HUKUM DAN PERUNDANGAN ISLAM VOLUME 8, NOMOR 2, OKTOBER 2018

p-ISSN 2089-0109; e-ISSN 2503-0922

Homepage: http://jurnalfsh.uinsby.ac.id/index.php/aldaulah

Email: judulsj@gmail.com 
tapi wajib memahami secara rinci tentang kehidupan di wilayahnya; ketiga, Indonesia seharusnya memiliki lima pilar kebangsaan seperti rakyat, TNI, Intelektual, adat dan budaya, dan kekuatan spiritual yang menopang tegak dan kokohnya Negara Kesatuan Republik Indonesia yang tata tentren kerta raharja.

Kata Kunci: Konsep negara, Cak Nun, Indonesia.

\section{Pendahuluan}

Di abad modern dan kontemporer seperti sekarang ini, diskusi tentang Negara selalu menarik dan tetap saja relevan. Karena ketika berbicara mengenai Negara, maka secara tidak langsung akan berbicara mengenai kekuasaan. Secara internasional, pengelolaan kekuasaan merupakan isu yang selalu terbaharui. Diskusi tentang kekuasaan tetap penting terutama ketika umat manusia berkepentingan untuk terus menemukan cara bagaimana menyeimbangkan kekuasaan. ${ }^{1}$ Jika distribusi kekuasaan seimbang, maka keamanan internasional otomatis akan bisa dijamin. Keseimbangan distribusi kekuasaan adalah cita-cita semua bangsa. Keseimbangan kekuasaan dibutuhkan persis di saat kekuatan bersenjata dan militerisme antarnegara seolah sampai pada taraf yang sangat kompetitif, sehingga mengkhawatirkan terjadinya perang. Penindasan dan perlakuan tidak adil akan berkurang dengan sendirinya jika konsep kekuasaan bisa dibenahi ${ }^{2}$. Tatanan Dunia dengan kekuasaan yang berimbang adalah tatanan dunia sebagaimana yang diharapkan bersama.

Tidak ketinggalan seniman sekaligus budayawan seperti Emha Ainun Nadjib ${ }^{3}$ pun memberikan komentarnya mengenai Negara

\footnotetext{
I Michael Sheehan, The Balance of Power: HistorTheory (London: Routledge, 1996), I 46.

2 Berkowitz, M.W. Educating for character and democracy: A practical introduction. Inucci Morall'd articles (pp. I-14). 1998.

3 Untuk selanjutnya nama Emha Ainun Nadjib akan disingkat menjadi Cak Nun. Muhammad Ainun Nadjib atau biasa dikenal Emha Ainun Nadjib atau Cak Nun lahir di Jombang, Jawa Timur, 27 Mei 1953 adalah seorang tokoh intelektual yang mengusung nafas Islami di Indonesia. la merupakan anak keempat dari 15 bersaudara. Beliau juga merupakan tokoh, seniman, budayawan dan da'i. Dalam kesehariannya beliau terjun langsung ke masyarakat dan melakukan kegiatan-kegiatan yang merangkum dan memadukan dinamika sosial, agama, pendidikan dan juga politik guna menumbuhkan potensial masyarakat
} 
dan Kuasa. Namun dalam perkembangannya komentarkomentarnya tersebut tampak sebagai sebuah kritikan dan cambukan tersendiri bagi pemerintah. Bagi Cak Nun sendiri ia memberikan kririkan bukan lantas berarti tidak suka ataupun hendak melawan pemerintahan yang ada, akan tetapi sebaliknya ia sangat cinta terhadap negara Indonesia oleh karenanya ingin memberikan sumbangsih sebuah pemikiran (politik) mengenai sebuah konsep negara yang bagus menurutnya untuk dijalankan oleh Indonesia kedepannya. Cak Nun memandang kegaduhan dan berbagai macam permasalahan yang ada di Indonesia selama terjadi akibat adanya kesalahan mendasar terutama dalam segi mengkonsep negara. Cak Nun memandang ada yang salah dalam mengartikan Konsep Negara selama ini.

Subagaimana diketahui bersama bahwa Negara Indonesia mengadopsi sistem dari Barat dengan menggunakan sistem presidensiil yang menyatukan kedudukan kepala negara dan kepala pemerintahan. Dalam pemerintahan presidensial tidak ada pemisahan antara fungsi kepala negara dan fungsi kepala pemerintahan, kedua fungsi terebut dijalankan oleh Presiden ${ }^{4}$. Dalam hal ini salah satu tokoh berpengaruh Cak Nun mengkritisi sekaligus memberi tawaran pemikiran tentang konsep Negara dan pemerintahan. Menurut Cak Nun bangsa ini belum memahami perbedaan antara Rakyat, Negara dan Pemerintahan, meskipun Cak Nun meyakini suatu saat nanti bangsa Indonesia akan mulai memahami perbedaan itu, karenanya bangsa Indonesia menurut Cak Nun masih belum beradab. Dalam hal ini Cak Nun mengatakan:

"Sampai saat ini kita masih belum benar-benar beradab karena membiarkan posisi rancu antara negara dan pemerintahan. Defacto kepegawaian bangsa ini adalah "pegawai Sipil pemerintah", sehingga konsentrasi ketaatan mereka adalah

${ }^{4}$ Franklin B. Weinstein, Indonesian Foreign Policy and The Dilemma of Dependence (Ithaca: Cornell University Press, 1976). 
kepada 'atasan' dalam struktur pemerintahan. Bukan ketaatan kepada Undang-undang Negara, apalagi pengabdian kepada Juragan Agung yang bernama Rakyat. ${ }^{5}$

Menurut Emha Ainun Nadjib rakyat membangun 'rumah' yang bernama Negara beserta tata aturannya (konstitusi, hukum dan tata kelola atau birokrasi). Di dalam rumah itu PNS, PSN, PSR, AR, PR atau BR adalah sekumpulan buruh (nya) rakyat yang digaji, disediakan fasilitas-fasilitas dan dijamin hidupnya hingga meninggal dunia sebatas kemampuan rakyat. Para petugas atau buruh yang digaji rakyat itu sementara ini menyebut dirinya pemerintah. Tetapi kalau pegawai negara, langsung menjelaskan bahwa pegawai mengabdi kepada negara dengan undangundangnya yang padat. Pegawai bukan mengabdi dan patuh kepada kepala kantornya, kepada lurah, camat, bupati, gubernur, menteri atau presiden. Semua 'padatan' dari lurah hingga presiden itu beserta semua pegawai negara, bersama-sama mengabdi kepada undang-undang negara, sebagai salah satu perwujudan pengabdian mereka kepada rakyat.

Dengan prinsip di atas presiden hingga lurah bukan 'atasan'nya pegawai negara, karena mereka berposisi sama di depan Undang-undang dan Hukum. Bahwa ada pembagian kewajiban dan hak yang tidak sama, ada tatanan hirarki kewenangan yang berbeda, itu pada akhirnya tidak berstruktur vertikal, melainkan merupakan putaran dinamis "division of labour"6. Gedung-gedung perkantoran, misalnya yang digunakan untuk bekerja oleh camat, rumah dinas bupati, mobil dinas Gubernur, fasilitas-fasilitas Presiden dan Menteri dan semua perangkat yang dipakai oleh pemerintah, bukanlah milik pemerintah, melainkan merupakan bagian dari fasilitas negara yang seluruhnya dimiliki oleh rakyat.

5Muhammad Ainun Nadjib, Pamangku Buwono Mamayu Bawono 2 September 2015 (caknun.com).

'Rizal Sukma, 'The evolution of Indonesia's foreign policy: an Indonesian view'. Asian Survey, 35 (3) (1995). 304-3 I5; URL: http://www.jstor.org/stable/2645547 Accessed: 06/06/20 I 8 00:53 
Sederhananya, menurut Cak Nun, bangsa ini harus menyadari beda antara keluarga dengan rumah tangga, antara kepala keluarga dengan kepala rumah tangga, termasuk antara almari kas negara dengan laci kas rumah tangga, juga antara Bendahara dengan dengan kasir. Minimal bangsa ini nanti akan belajar kepada Tri Bhuwana Tungga Dewi pemikir dan pengarif kebesaran Majaphit, kepada Hayam Wuruk dan Gadjah Mada, dalam hal tata kelola kesejahteraan Rakyat juragan mereka. ${ }^{7}$

Pemikiran politik Cak Nun mengenai konsep negara di atas menarik untuk dibahas secara mendalam, apalagi ketika kondisi perpolitikan di Indonesia yang carut-marut seperti saat ini. Bisa jadi sekilas pemikiran politik Cak Nun tersebut cocok apabila diterapkan di Indonesia. Oleh karena itulah nantinya akan dibahas mengenai Konsep Negara Menurut Cak Nun dan relevansinya terhadap Negara Indonesia. Dengan demikian artikel ini akan menjawab persoalan seputar konsep negara dan bagaimana relevansinya dengan Indonesia sekarang ini dalam perspektif Emha Ainun Nadjib yang dikenal dengan sebutan Cak Nun.

\section{Sejarah Sistem Pemerintahan Indonesia}

Sistem pemerintahan awal yang digunakan oleh Indonesia adalah sistem pemerintahan presidensial yang merupakan adopsi dari dunia barat. Adanya Konferensi Meja Bundar (KMB) antara Indonesia dengan delegasi Belanda menghasilkan keputusan pokok bahwa kerajaan Belanda mengakui kedaulatan Indonesia sepenuhnya tanpa syarat dan tidak dapat dicabut kembali kepada RIS seambat-lambatnya pada tanggal 30 Desember 1949. Dengan ditetapkannya RIS, sistem pemerintahan yang digunakan adalah parlementer. Namun karena tidak seluruhnya diterapkan maka sistem pemerintahan saat itu disebut Parlementer semu ${ }^{8}$. 
UUDS 1950 adalah konstitusi yang berlaku di negara Republik Indonesia sejak 17 Agustus 1950 hingga dikeluarkannya Dekrit Preiden 5 Juli 1959. Pemilihan Umum 1959 berhasil memilih konstituante secara demokrtatis, namun konstituante gagal membentuk konstitusi baru hingga berlarut-larut. Pada tanggal 5 Juli 1959 pukul 17.00, Presiden Soekarno mengeluarkan dekrit yang diumumkan dalam upacara resmi di Istana Merdeka. Demokrasi pada masa ini dikenal dengan sebutan demokrasi parlementer. Sistem ini mulai berlaku sebulan setelah kemerdekaan diproklamasikan. Kemudian diperkuat dalam UUD 1949 (konstitusi RIS) dan UUDS 1950. Sistem ini kurang cocok diterapkan di Indonesia. Terlihat dari melemahya persatuan bangsa ${ }^{9}$.

Dalam UUDS 1950, badan eksekutif terdiri dari presiden sebagai kepala negara kostitusional dan perdana menteri sebagai kepala pemerintahan. Demokrasi terpimpin sebenarnya ingin menempatkan Soekarno sebagai "Ayah" dalam famili besar bernama Indonesia dengan kekuasaan pusat di tangannya. Dengan demikian, kekeliruan yang besar dalam Demokrasi Terpimpin Soekaro adalah adanya pengingkaran terhadap nilai-nilai demokrasi yaitu absolutisme dan terpusatnya kekuasaan hanya pada diri pemimpin. Selain itu, tidak ada ruang kontrol sosial dan check and balance dari legislatif terhadap eksekutif. Ciri-ciri demokrasi pada periode Orde Lama antara lain presiden sangat mendominasi pmerintahan, terbatasnya peran partai politik, berkembangnya pengaruh komunis dan meluasnya peran ABRI sebagai unsur sosial politik ${ }^{10}$.

Peralihan orde lama ke orde baru merupakan berubahnya sebuah rezim yang sangat kontras dari kepemmpinan Soekarno ke Soeharto. Kemudian orde baru tumbang dengan melahirkan orde reformasi yang ditandai dengan turunnya Presiden Soeharto pada tanggal 21 Mei 1998. Jabatan Presiden kemudian diisi oleh wakil presiden, Prof. DR. Ir. Ing. B.J. Habibie. Turunnya Presiden Soeharto 
disebabkan karena tidak adanya lagi kepercayaan dari rakyat terhadap pemerintahan Orde Baru. Bergulirnya reformasi yang mengiringi keruntuhan rezim tersebut menandakan tahap awal bagi transisi demokrasi Indonesia. Transisi demokrasi merupakan fase krusial yang kritis karena dalam fase ini akan ditentukan ke mana arah demokrasi akan dibangun ${ }^{11}$.

Berdasarkan potret berubahnya sistem pemerintahan yang berubah-ubah, Indonesia belum menemukan sistem pemerintahan yang benar-bear relevan dengan kondisi bangsa Indonesia saat itu sendiri. Padahal sistem pemerintahan RI menurut UUD 1945 tidak menganut suatu sistem dari negara manapun, melainkan suatu sistem yang khas bagi bangsa Indonesia. Hal ini tercermin dari proses pembentukan bangsa NKRI yang digali dari nilai-nilai kehidupan bangsa Indonesia sendiri. Menurut UUD 1945, kedudukan presiden sebagai kepala negara dan kepala pemerintahan. Sistem ketatanegaraan yang kepala pemerintahannya adalah Presiden dinamakan sistem presidensial. Presiden memegang kekuasaan tertinggi negara di bawah pengawasan Majelis Permusyawaratan Rakyat. Dalam pelaksanaan sistem pemerintahan ini, terdapat beberapa perubahan pokokpokok sistem pemerintahan Indonesia, sebelum dan sesudah amandemen UUD 1945.12

\section{Pemikiran Politik Cak Nun Tentang Konsep Negara}

Pembentukan negara adalah sebuah keniscayaan yang tidak dapat terelakkan. Etika politik modern mengatakan bahwa tujuan utama penyelenggaraan negara adalah menciptakan kehidupan yang sejahtera di antara sesama warga negaranya. Negara juga merupakan sebuah organisasi kekuasaan yang dengan kekuasaannya tersebut mengusahakan kebaikan-kebaikan bagi manusia. Artinya, apakah yang paling baik bagi manusia lahir dan batin, berarti di sana terdapat wilayah rakyat, pemerintah dan 
tujuan serta penyelenggaraan tujuan yang akan diwujudkan tersebut. ${ }^{13}$

Dalam QS, Saba': 15 disinggung tentang gambaran negara yang baik, makmur dan sejahtera agar manusia menerapkan sistem yang mampu membuat seperti maksud ayat di atas. Allah sendiri sudah membuka pintu maaf untuk orang-orang yang serius dalam mengurus negara, karena memang tidak ada manusia yang lepas dari kesalahan. Kesalahan merupakan sifat yang menjadikan manusia sempurna. Karena manusia tempatnya salah dan lupa. Allah menyatakan Ghafu>r (memaafkan) ketika manusia memang benar-benar serius dalam mengurus negara walaupun di dalamnya terdapat kesalahan-kesalahan. Menurut pandangan Cak Nun, mewujudkan konsep baldatun thoyyibatun warobbun ghafu>r erat kaitannya dengan istilah tata tentrem kerta raharja, karena di Jawa sendiri keadaan alamnya digambarkan dengan istilah gemah ripah loh jinawi merupakan kesuburan dan kekayaan alam yang melimpah diberikan Tuhan, sehingga masyarakat Jawa untuk mengolah dan mengembangkan alam oleh sebuah tatanan masyarakat yang disepakati sebagai tata tentrem kerta raharja. ${ }^{14}$

Terbentuknya negara harus menciptakan ketentraman bagi masyarakatnya. Cak Nun dalam buku keempatnya yang berjudul "Secangkir Kopi Jon Parkir" dicetak pertama kali pada tahun 1992 mengungkapkan bahwa:

"Negara menghendaki stabilitas. Masyarakat menghendaki ketertiban. Sejarah menghendaki keamanan. Jiwa menghendaki ketenangan. Hati menghendaki keheingan. Mental menghendaki endapan dan seluruh kehidupan ini, diujungnya nanti, menghendaki ketentraman, kebeningan, kemurnian."15

Bagi penulis sendiri negara berpotensi menciptakan itu semua, karena rakyat mengendaki terbentuknya negara dengan harapan mampu menciptakan ketentraman, sejatinya seluruh kehidupan ini

I3Moch. Tolchah Mansoer, Konsep Dasar Islam tentang Negara, (Purworejo; PTII, 1997), 8.

${ }^{14}$ Maiyahan Taman Sari Art Fertival, (Plaza Ngasem, Yogyakarta) 24 Juli 2014. Lihat juga di "buletin mocopat syafa'at edisi 78," I4.

${ }^{15}$ Emha Ainun Nadjib, Secangkir Kopi John Parkir, cet. VI (Bandung: Mizan, 1996), 373. 
di ujungnya nanti ketentraman, keheningan, kemurnian karena agama juga menganjurkan kembali ke fitri (idul fitri). Fitri adalah suci/murni, karena kesucian dan kemurnian membuat ketentraman bagi seluruh rakyat dengan otoritas yang dimiliki lembaga negara, tidak terkecuali di negara Indonesia.

Bagi Cak Nun, Indonesia saat ini perlu berkaca kembali ke sejarah masa silam, karena sejarah masa silam bangsa Indonesia yang disebut Nusantara, jauh lebih baik dibanding keadaan negara Indonesia saat ini. Formasi kebangsaan Indonesia sekarang, memang disusun oleh sejarah kolonialisme yang telah menjajah rakyat Indonesia puluhan hingga ratusan tahun. Sebagai antisipasi yang paling mungkin terhadap momentum-momentum kemanusiaan di penghujung kolonialisme. Ada beberapa bentuk penjajahan yang sebaiknya masyarakat pahami, agar mampu mengantisipasi dan sebagai bentuk kuda-kuda yang kuat terhadap penetrasi kolonialisme di jaman modern ini. Mulai dari penjajahan fisik, nilai, budaya, pasar, hingga kemudian penjajahan regulasi. Saat ini di Indonesia sedang mengalami penjajahan regulasi, dimana aturan-aturan yang menjadi dasar dalam melakukan sesuatu dirubah dengan tujuan tidak menyadari bahwa sedang dijajah, karena aturan yang dimaksud sudah mengizinkan. ${ }^{16}$ Sebagai contoh para koruptor saat ini tidak memikirkan bagaimana cara mencuri uang negara agar tidak ketahuan, tetapi merupakan hal yang sering Cak Nun sampaikan kepada masyarakat, karena keris adalah lambang budaya, pamor, pusaka orang Jawa. Tanpa pusaka, orang Jawa menjadi bukan orang Jawa, karena ketika kehilangan pusaka bisa berakibat kehilangan budaya adiluhung yang dijunjung dalam hati dan dibela sepenuh jiwa. ${ }^{17}$

Dalam wawancara dengan Cak Nun yang diliput TVRI Jawa Tengah, Cak Nun berpendapat bahwa di Indonesia sekarang ini tidak adanya perbedaan antara lembaga negara dan lembaga

16Maiyahan Taman Sari Art Fertival, (Plaza Ngasem, Yogyakarta) 24 Juli 20 I4. Lihat juga di "Buletin Mocopat Syafa'at Edisi 78," 8.

${ }^{17} \mathrm{bid}$, 
pemerintahan yang menurutnya tidak logis. Sudah semestinya dalam sebuah negara harus bisa membedakan antara lembaga negara dan lembaga pemerintah, demi terciptanya kestabilan politik dalam suatu negara. Lembaga pemerintah yang dikepalai oleh kepala pemerintahan seharusnya patuh dan taat kepada kepala negara, karena kepala pemerintahan beserta bawahannya hanya bekerja dengan sistem kontrak yang pada umumnya di Indonesia lima tahun lamanya. Dalam hal ini Cak Nun tidak sependapat dengan konsep pemerintahan di Indonesia saat ini. Tidak sependapat, bukan berarti melawan, akan tetapi tidak setuju dengan konsep pemerintahan saat ini. ${ }^{18}$ Kebebasan berpendapat tidak dilarang di dalam negara demokrasi. Termasuk pendapat tentang ketidaksetujuan Cak Nun dengan pemerintahan Indonesia saat ini.

Perlu adanya perbedaan antara kepala negara dan kepala pemerintahan, pernah disampaikan Cak Nun dalam acara kuliah budaya yang diselenggarakan forum "Pergerakan Indonesia", organisasi yang didirikan Anas Urbaningrum. Urusan negara sebaiknya tidak hanya mengandalkan para politisi dan para aktivis pergerakan, sebab itu hanya masalah hukum, konstitusi dan kekuasaan. Dalam mengurus negara, harus mau melihat sejarah yang memerlukan seorang begawan, kaum brahmana, butuh panembahan dan butuh rohaniawan, dulu disebutnya sebagai DPA (Dewan Pertimbangan Agung).

Tidak adanya perbedaan antara negara dan pemerintah terlihat ketika dibandingkan pada zaman Majapahit, kepala negaranya adalah Hayam Wuruk dan kepala pemerintahannya adalah Gajah Mada. Oleh karena itu, kas negara dan kas pemerintah berbeda. BUMN nya Majapahit tidak setor ke menterinya Gajah Mada, tetapi ke kas negaranya Hayam Wuruk, yang selanjutnya disupply sekian persen untuk APBD Majapahit. Mengambil contoh, KPK adalah lembaga negara, yang seharusnya melantik kepala KPK 
bukanlah presiden, karena presiden adalah orang nomor satu yang harus diawasi oleh lembaga KPK. ${ }^{19}$

Hal ini terjadi di negara Indonesia saat ini tidak membedakan antara lembaga negara dan lembaga pemerintah. Dalam negaranegara yang ada di dunia, mungkin bisa melihat ke negara Inggris yang pemerintahannya menggunakan sistem pemerintahan parlementer. Menurut Maurice Duverger, negara dengan pola dasar Inggris memperlihatkan tiga ciri yaitu: demokrasi, liberal, parlementer. ${ }^{20}$ Dalam sistem demokrasi di Inggris, semua pejabat negara dipilih dalam pemilihan umum yang bebas dan rahasia, kecuali raja/ratu yang berperan sebagai kepala negara diangkat dengan cara otokratis. Dalam pola dasar negara Inggris, yang memegang peranan aktif dan penting dalam pemerintahan adalah kabinet (Perdana Menteri yang disebut juga kepala pemerintah dan Menteri-Menteri) dan parlemen. Sementara Mahkota (Raja/Ratu) hanyalah merupakan lambang kesatuan bangsa Inggris. ${ }^{21}$

Pilar kebangsaan Indonesia merupakan pilar bangunan suatu negara, menurut pandangan Cak Nun empat pilar yang sekarang dianut secara nasional tidak berada dalam konfigurasi bahan, ketinggian dan kekuatan. Pilar adalah sesuatu yang menyangga bangunan, sebagai kekuatan atas berdirinya suatu negara. ${ }^{22}$ Indonesia seharusnya memiliki lima pilar kebangsaan, misalnya ${ }^{23}$ :

Pertama, Rakyat. Yang menjadi bangunan pokok dalam negara Indonesia adalah rakyat, selanjutnya dari rakyat akan muncul pilarpilar yang lain. Kedua, TNI atau tentara Rakyat. TNI berperan sebagai lembaga pertahanan untuk melindungi rakyat dan itu pun diambil dari kalangan rakyat mulai dari panglima jendral hingga

\footnotetext{
${ }^{19}$ Kuliah Budaya yang diselenggarakan Forum Pergerakan Indonesia dengan Tema: "Supremasi Keadilan dan Supremasi hukum" di rumah pergerakan I3 November 2003.

${ }^{20}$ Bai, L. Monetary Reward Versus the National Ideological Agenda: Career Choice Among Chinese University Students. Journal of Moral Education, 27(4), (1998). 525-540. http://dx.doi.org/l 0. I 080/0305724980270406

${ }^{21}$ Kansil CST. Hukum AntarT ata Pemerintahan, (Jakarta : Erlangga, 1987).

22Wawancara Tim SAKSI "Satu Kamera Sejuta Inspirasi : Bersama Emha Ainun Nadjib"

${ }^{23}$ Dewi Fortuna Anwar, Indonesia in ASEAN. Foreign Policy and Regionalism. (Singapore: Institute of Southeast Asian Studies. 1991).
} 
babinsa. Ketiga, Intelektual. Kaum Intelektual bisa berasal dari para seniman, pelajar, para ahli dan segala ahli yang berkaitan dengan bidang-bidang yang ada di indonesia, karena golongan ini termasuk golongan yang berperan dalam pembuatan undangundang di segala bidang. Keempat, Adat dan Budaya. Tidak sepantasnya berdirinya sebuah negara justru malah menghilangkan kebudayaan yang ada pada masing-masing daerah, karena adat merupakan warisan peradaban yang bernilai luhur dari orangorang terdahulu di masing-masing daerah. Kelima,Kekuatan Spiritual. Spiritual biasanya dibawakan agama dan juga berkaitan juga dengan pilar yang keempat.

Kelima pilar di atas seharusnya seimbang, tidak boleh bertumpu pada satu atau dua pilar saja, sebagaimana Indonesia dengan konsep empat pilarnya (Pancasila, Bhineka Tunggal Ika, UUD 1945 dan NKRI) yang dulu pernah bertumpu hanya pada pilar yang pertama yaitu pilar Pancasila. ${ }^{24}$

\section{Kriteria Pemimpin dalam Pandangan Cak Nun}

Menurut Cak Nun, untuk mewujudkan konsep tata tentrem kerta raharja diperlukan beberpa kriteria, seperti halnya disampaikan dalam acara Mocopat Syafa' at di Jogja :

"Yang diperlukan untuk mencapai negeri yang tata tentrem kerta raharja ini adalah seorang pemimpin yang memiliki pemahaman menyeluruh dan rinci, bukannya seorang politisi yang dirinya pengetahuannya sangat sempit dan dirinya dipenuhi kepentingan-kepentingan pribadi dan golongannya. Ia tidak boleh hanya memiliki pengetahuan yang sifatnya global, tetapi harus sampai pada pemahaman tingkat spesialis yang beragam." 25

Pernyataan Cak Nun tersebut, dimaksudkan untuk menjadi seorang pemimpin, dibutuhkan kualitas keilmuan yang tidak hanya sekedar mengetahui persoalan yang bersifat untuk kepentingankepentingan pribadi dan golongannya, tetapi wajib memahami

24Maiyahan Taman Sari "Buletin Mocopat Syafa'at: Bundel 20/4" edisi 74, 4.

${ }^{25}$ Dalam Buletin Mocopat Syafa'at, Edisi 78, 17 Desember 20I4 - 17 Januari 20I5, (Produksi Djanurkoening), 14. 
secara rinci tentang kehidupan di wilayahnya. Tidak menutup kemungkinan dalam soal pemimpin negara di Indonesia, karena mengingat persoalan kenegaraan di Indonesia yang sangat beragam dan penduduk Indonesia juga terdiri atas berbagai macam suku di dalamnya, sehingga saat ini Bhineka Tunggal Ika menjadi moto atau semboyan negara. Disamping itu, istilah Tata tentrem Kerta Raharja, yang menurutnya berkaitan dengan konsep negara dalam Islam yaitu Baldatun thayyibatun wa rabbun ghafur, perbedaan terletak pada kata rabbun ghafur.

Jika pada masyarakat baldatun thoyyibatun syaratnya adalah adanya kesepakatan atau perjanjian antar manusia atau antar kelompok yang ada dalam kumpulan manusia tersebut, maka untuk mencapai masyarakat rabbun ghafur, yang dijanjikan ampunan Allah, masyarakat tersebut harus sudah pada tingkatan saling memaafkan satu sama lain. Misalnya, rakyat kepada pemimpin yang melakukan kesalahan dengan tidak sengaja. Seperti disinggung dalam sebuah hadis yang mengatakan Allah tidak akan mengampuni suatu kesalahan seseorang, sebelum ia minta maaf kepada orang yang dizalimi. Di samping itu, pemimpin juga harus serius dan sungguh-sungguh dalam melaksanakan kewajibannya berupa amanat yang diterimanya walaupun dalam pelaksanaannya terdapat kesalahan. Kesalahan juga bisa terjadi akibat adanya perbedaan kelompok ataupun perbedaan pendapat dalam suatu negara, karena suatu negara tergabung beberapa suku di dalamnya, sehingga perbedaan akan mudah sekali terbentuk. Untuk mencapai sebuah masyarakat yang mampu memaafkan satu sama lain, diperlukan kemampuan untuk memiliki pemahaman yang baik terhadap satu sama lain dan kedewasaan untuk menerima perbedaan.

Perbedaan memang harus ada, karena demikian hakikatnya sebuah negara dengan keragaman rakyatnya. Jika memang perbedaan itu terlalu tajam, diperlukan adanya otoritas negara yang 
dipercaya semua orang. ${ }^{26}$ Misalnya pihak kepolisian yang bertugas untuk mengatasi dan mengantisipasi terjadinya konflik antarwarga. Mengantisipasi dan mengatasi konflik di masyarakat memang sudah menjadi fungsi adanya negara, karena negara bertujuan untuk menciptakan kestabilan politk, budaya, agama yang sering mengalami benturan-benturan ${ }^{27}$.

\section{Relevansi Pemikiran Politik Cak Nun}

Seperti diketahui bersama bahwa Negara Indonesia mengadopsi sistem dari Barat dengan menggunakan sistem presidensil yang menyatukan kedudukan kepala negara dan kepala pemerintahan ${ }^{28}$. Dalam pemerintahan presidensial tidak ada pemisahan antara fungsi kepala negara dan fungsi kepala pemerintahan, kedua fungsi terebut dijalankan oleh Presiden ${ }^{29}$. Hal ini adalah fakta yang dilihat bersama bahwa memang dalam sistem pemerintahan di Indonesia menjadikan satu makna antara kepala pemerintahan dan kepala negara.

Sementara itu menurut Cak Nun sebagai seorang budayawan sekaligus seniman mengkritisi sekaligus memberi tawaran pemikiran tentang konsep Negara dan pemerintahan. Menurut Cak Nun bangsa ini belum memahami perbedaan antara Rakyat, Negara dan Pemerintahan, meskipun Cak Nun meyakini suatu saat nanti bangsa Indonesia akan mulai memahami perbedaan itu, karenanya bangsa Indonesia menurut Cak Nun masih belum beradab. Cak Nun berpendapat bahwa di Indonesia sekarang ini tidak adanya perbedaan antara lembaga negara dan lembaga pemerintahan yang menurutnya tidak logis. Sudah semestinya dalam sebuah negara harus bisa membedakan antara lembaga negara dan lembaga pemerintah, demi terciptanya kestabilan politik dalam suatu

\footnotetext{
$26 \mathrm{bid}, 14$

${ }^{27}$ Herbert Feith, The decline of constitutional democracy in Indonesia. (Ithaca: Cornell University Press. 1962).

${ }^{28}$ Bachtiar Effendy, , Islam and the state in Indonesia (Singapore: Institute of Southeast Asian Studies. 2003).

${ }^{29}$ Marcus Mietzner, Military politics, Islam and the state in Indonesia: from turbulent transition to democratic consolidation (Singapore: Institute of Southeast Asian Studies. 2009).
} 
negara. Selain itu bagi Cak Nun, Indonesia saat ini perlu berkaca kembali ke sejarah masa silam, karena sejarah masa silam bangsa Indonesia yang disebut Nusantara, jauh lebih baik dibanding keadaan negara Indonesia saat ini. Formasi kebangsaan Indonesia sekarang, memang disusun oleh sejarah kolonialisme yang telah menjajah rakyat Indonesia puluhan hingga ratusan tahun. Sebagai antisipasi yang paling mungkin terhadap momentum-momentum kemanusiaan di penghujung kolonialisme. Ada beberapa bentuk penjajahan yang sebaiknya masyarakat pahami, agar mampu mengantisipasi dan sebagai bentuk kuda-kuda yang kuat terhadap penetrasi kolonialisme di jaman modern ini. Mulai dari penjajahan fisik, nilai, budaya, pasar, hingga kemudian penjajahan regulasi.

Jika dilihat memang terjadi anomali antara pemikiran politik Cak Nun dengan realita konsep negara Indonesia saat ini. Relevansinya adalah perlu adanya re-orientasi mengenai konsep negara itu sendiri, apa yang disampaikan Cak Nun tidak lantas dibenarkan seratus persen, terlebih pendapatnya bahwasannya Indonesia perlu mengaca dan kembali seperti halnya kerajaan Mataram pada masa lalu, karena bagaimanapun kondisi sekarang ini dengan kondisi masa lampau jauh sangat berbeda. Namun pendapat Cak Nun yang demikian tidak sepenuhnya juga disalahkan, karena bagaimanapun kondisi perpolitikan dan sistem pemerintahan yang ada di Indonesia sekarang ini masih jauh dikatakan sempurna, buktinya masih banyak rakyat Indonesia yang belum sejahtera dan mendera kemiskinan berkepanjangan, seolaholah rakyat masih terjajah namun bentuk jajahannya dalam bentuk yang lain, sebagaimana yang dikatakan Cak Nun sebelumnya. Oleh karena itu perlu adanya evaluasi terhadap semuanya terlebih terhadap konsep dan sistem pemerintahan Indonesia.

Apa yang dikatakan Cak Nun bahwa bangsa Indonesia perlu kembali dan mengaca pada masa lalu (Nusantara) mungkin tidak bisa dipraktekkan sepenuhnya, namun mungkin ada nilai-nilai sistem pemerintahan yang bisa diambil dan diterapkan sekarang. Tidak hanya dalam hal itu, dalam pendapatnya mengenai antara 
kepala negara dan kepala pemerintahan dan dalam semua pemikiran politik Cak Nun ada nilai-nilai yang bisa diambil dan diimplementasikan terhadap Indonesia saat ini untuk perubahan ke arah yang lebih baik.

\section{Penutup}

Dari pemaparan di atas, beberapa hal mengenai pemikiran politik Cak Nun mengenai sistem pemerintahan dan Konsep Negara. Menurut Cak Nun di Indonesia sekarang ini terdapat kerancauan dalam beberapa istilah, oleh karenanya banyak sekali terjadi ambiguitas tugas dan kerja pejabat dan pembagian kerja. Seperti seharusnya perlu dibedakannya antara istilah kepala negara dan kepala pemerintahan, karena memang kedua hal tersebut mempunyai dua hal tugas dan tanggung jawab yang berbeda. Selain itu juga perlu dibedakannya antara lembaga Negara dan lembaga pemerintahan. Gara-gara tidak bisa membedakan dua istilah itu bisa dikatakan bukan bangsa yang beradab karena masih belum benar-benar beradab karena membiarkan posisi rancu antara negara dan pemerintahan. Selain hal itu diperlukan juga membedakan dan merenungi makna dari Rakyat, Negara dan Pemerintah.

Bagi Cak Nun, Indonesia saat ini perlu berkaca kembali ke sejarah masa silam, karena sejarah masa silam bangsa Indonesia yang disebut Nusantara, jauh lebih baik dibanding keadaan negara Indonesia saat ini. Formasi kebangsaan Indonesia sekarang, memang disusun oleh sejarah kolonialisme yang telah menjajah rakyat Indonesia puluhan hingga ratusan tahun. Sebagai antisipasi yang paling mungkin terhadap momentum-momentum kemanusiaan di penghujung kolonialisme. Ada beberapa bentuk penjajahan yang sebaiknya masyarakat pahami, agar mampu mengantisipasi dan sebagai bentuk kuda-kuda yang kuat terhadap penetrasi kolonialisme di zaman modern ini. Mulai dari penjajahan fisik, nilai, budaya, pasar, hingga kemudian penjajahan regulasi. 


\section{Daftar Pustaka}

Anwar, Dewi Fortuna. Indonesia in ASEAN. Foreign policy and regionalism. Singapore: Institute of Southeast Asian Studies. 1991.

Assegaff, Zaman Keemasan Soeharto, Jakarta : Kompas, 2013.

Bai, L. Monetary Reward Versus the National Ideological Agenda: Career Choice among Chinese University Students. Journal of Moral Education, 27(4), (1998). 525-540. http://dx.doi.org/10.1080/0305724980270406

Berkowitz, M.W. Educating for character and democracy: A practical introduction. Inucci Morall'd articles (pp. 1-14). 1998.

Buletin Mocopat Syafa'at, Edisi 78, 17 desember 2014 - 17 januari 2015. CST. Kansil, Hukum antar Tata pemerintahan, Jakarta : Erlangga, 1987. Effendy, Bachtiar. Islam and the state in Indonesia. Singapore: Institute of Southeast Asian Studies. 2003.

Erianto, Analisis Wacana (Pengantar analisis teks media, Yogyakarta : LkIS, 2006.

Feith, Herbert. The decline of constitutional democracy in Indonesia. Ithaca: Cornell University Press. 1962.

Latif ,Yudi dan Idi Subandi Ibrahim, Bahasa dan Kekuasaan Politik Wacana di Orde Baru, Bandung : Mizan, 1996.

Mansoer, Tolchah, Moch., konsep Dasar Islam tentang Negara, Purworejo; PTII, 1997.

Mietzner, Marcus. Military Politics, Islam and The State in Indonesia: from Turbulent Transition to Democratic Consolidation. Singapore: Institute of Southeast Asian Studies, 2009.

Nadjib, Ainun, Emha, Jejak Tinju Pak Kyai, Jakarta : Kompas, 2009.

Nadjib, Ainun, Emha, Secangkir Kopi John Parkir, cet. VI Bandung : Mizan, 1996.

Nadjib, Ainun,Emha, Kiai Sudrun Gugat, Bandung : Mizan, 1995.

Nadjib, Ainun,Emha, Opini Plesetan, Bandung : Mizan, 1995. 
Sheehan, Michael, The Balance of Power: HistorTheory, London: Routledge, 1996.

Sukma, Rizal. 'Insight: Debating Indonesia's Global Role'. Jakarta Post. Thursday, 11 March 2010.

Sukma, Rizal. 'The evolution of Indonesia's foreign policy: an Indonesian view'. Asian Survey, 35 (3) (1995). 304-315; URL: http://www.jstor.org/stable/2645547 Accessed: 06/06/2018 00:53

Weinstein, Franklin B. Indonesian foreign policy and the dilemma of dependence. Ithaca: Cornell University Press. 1976

Wirosardjono, Soetjipto, Dialog dengan Kekuasaan", (Bandung : Mizan, 1995). 